\title{
肺門型早期扁平上皮癌に対する肺切除を伴わない気管支形成の経験
}

\author{
鈴木 聡 1 保坂智子 1 ・新川弘道 1 ・ \\ 羽隅 透 1 ・渋谷丈太郎 1 ・半田政志 1
}

要旨一一背景. われわれは早期扁平上皮癌に対して肺実質を切除しない気管支形成を行った. 症例. 症例は 69 歳, 男 性．主訴は血痰．胸部 X 線写真では異常を認めなかったが，気管支鏡検査で右上葉気管支/中間幹分岐部に限局した隆 起病変を認め，その生検で扁平上皮癌と診断された。胸部 CT 写真では壁外浸潤はないと判断された。また，有意なり ンパ節腫大も認められなかった。右後側方切開で第 5 肋間から開胸し，右上葉気管支/中間幹分岐部をスリーブ状に切 除したのち単結節でテレスコープ状に吻合した. 2 群リンパ節郭清を行った. 術中迅速診断で気管支断端の近位側と遠 位側に腫瘍の遺残がないことを確認した。切除された腫瘍は中分化型扁平上皮癌で気管支軟骨への浸潤が認められた が壁外浸潤はなかった。リンパ節転移は認められなかった。術後の胸部レントゲン写真では全ての肺葉の含気が良好 で，気管支鏡検査では吻合部は上葉気管支，中間幹とも開存が良好であった。肺機能検査成績も良好に維持された，結 論. 早期の扁平上皮癌のなかには，本症例のように肺実質の切除を伴わない手術法が適応できる症例がある.（肺癌. 2002;42:197-201)

索引用語 ——早期扁平上皮癌, スリーブ切除, 気管支形成, 肺機能検査

\section{A Case of Hilar Type Early Squamous Cell Carcinoma Treated by Bronchoplasty Without Lung Resection}

\author{
Satoshi Suzuki ${ }^{1}$; Tomoko Hosaka ${ }^{1}$; Hiromichi Niikawa ${ }^{1}$; \\ Toru Hasumi ${ }^{1}$; Jotaro Shibuya ${ }^{1}$; Masashi Handa ${ }^{1}$
}

\begin{abstract}
Background. Bronchial sleeve resection and plasty techniques have been well established as routine procedures to avoid unnecessary removal of lung tissues. However, bronchoplasty without lung resection is still an uncommon alternative in the surgical treatment of early lung cancer. We report a case of early squamous cell carcinoma treated by bronchoplasty without lung resection. Case. A 69-year-old man was admitted with bloody sputum. Although his chest X-ray was normal, bronchoscopy revealed a polyp, approximately $1 \mathrm{~cm}$ in diameter, at the bifurcation of the right upper lobe bronchus and truncus intermedius. Biopsy yielded a diagnosis of squamous cell carcinoma. Chest CT showed no detectable invasion beyond the bronchial wall, or lymph node metastases. We employed bronchial sleeve resection and a telescope-like anastomosis technique, and the tumor was removed without lung resection. No tumor cells were detected on the cut surface of the right main, upper lobe bronchus and truncus intermedius. Postoperative lung function tests at 3 months showed no decrease in spirometory, lung volume or diffusion capacity. Conclusion. Selected cases of early squamous cell carcinoma of the lung can be treated with good results by bronchoplasty without lung resection. (JJLC. 2002;42:197-201)
\end{abstract}

KEY WORDS — Early squamous cell carcinoma of the lung, Sleeve resection, Bronchoplasty, Lung function test

1 仙台厚生病院外科.

別刷請求先：鈴木 聡, 東北大学加齢医学研究所呼吸器再建, テ980-8575 仙台市青葉区星陵町 4-1 (e-mail:satoshisuzuki@idac. tohoku.ac.jp).

1Department of Surgery, Sendai Kosei Hospital, Japan.

Reprints: Satoshi Suzuki, Department of Thoracic Surgery, In- stitute of Development, Aging and Cancer, Tohoku University, 41 Seiryo-machi, Aoba-ku Sendai, Miyagi 980-8575 Japan（e-mail: satoshisuzuki@idac.tohoku.ac.jp) .

Received January 28, 2002; accepted March 13, 2002.

(C) 2002 The Japan Lung Cancer Society 


\section{はじめに}

肺癌に対する外科療法のなかで，スリーブ肺葉切除な どの気管支形成術は，呼吸機能温存の観点からも重要な 手技として定着している。しかし，症例ごとの特異性に あわせた多様なバリエーションへの対応を求められる場 合がある. ${ }^{1}$ 今回，われわれは右上葉気管支/中間幹分岐 部に発生した早期扁平上皮癌に対して，その部位をス リーブ状に切除して肺実質を切除することなく腫瘍を摘 除する，という非定型的な気管支形成を行ったので報告 する。

\section{症 例}

症例：69 歳, 男性.

主訴：血痰.

既往歴：特記すべき事項なし.

職業：農業.

契煙歴：40 本 $\times 36$ 年.

現病歴: 平成 12 年 12 月に血痰が出現したため近医を 受診した. 気管支鏡検査を受け, 右上葉気管支/中間幹分 岐部に直径約 $1 \mathrm{~cm}$ の腫瘤を指摘され，同部位からの生 検で扁平上皮癌と診断された. 加療目的に平成 13 年 2 月 に当科に紹介となった。

入院時現症：身長 $154 \mathrm{~cm}$, 体重 $64 \mathrm{~kg}$. 血圧 130/86 $\mathrm{mmHg}$, 脈拍 $72 / \mathrm{min}$. 䏫部聴診でラ音や心椎音を聴取し なかった．表在リンパ節を触知しなかった．

肺機能検査: 肺活量 $3.68 \mathrm{~L}, 1$ 秒量 $2.36 \mathrm{~L}, 1$ 秒率 64.1 \%で，軽度の閉塞性障害を認めた。

胸部 X 線写真：異常陰影は認められなかった.

胸部 CT 写真：直径約 $1 \mathrm{~cm}$ の腫瘤が右上葉気管支/中 間幹分岐部から膜様部にかけて認められた，気管支壁外 への浸潤はなかった (Figure 1)．肺門や縦隔には有意な リンパ節腫大はなかった。

気管支鏡検査：ポリープ状の隆起病変が右上葉気管 支/中間幹分岐部から膜様部にかけて認められた（Figure 2). 直径は約 $1 \mathrm{~cm}$ で表面は易出血性であった。腫瘍より も未梢の右気管支上幹と中間幹には異常は認められな かった。

全身検索で胃体部前壁に陥凹病変が発見された。同部 位からの生検で腺癌 (signet cell) と診断され, 肺癌手術 後に胃全摘術を行う予定とした.

手術所見：平成 13 年 2 月に手術を行った.後側方切開 で右第 5 肋間から開胸した。はじめに気管支吻合部の被 覆に用いるように，第 5 肋間筋を $20 \mathrm{~cm}$ にわたり有荎つ ラップに作成した. ついで, リンパ節＃9，\#10，\#7,

\#11s, \#12u，＃11i，＃1，\#2，\#3，＃4，\#3a を郭清 した. \#3p は認められなかった. 主気管支, 右上葉気管 支，および中間幹にそれぞれテーピングして確保したの

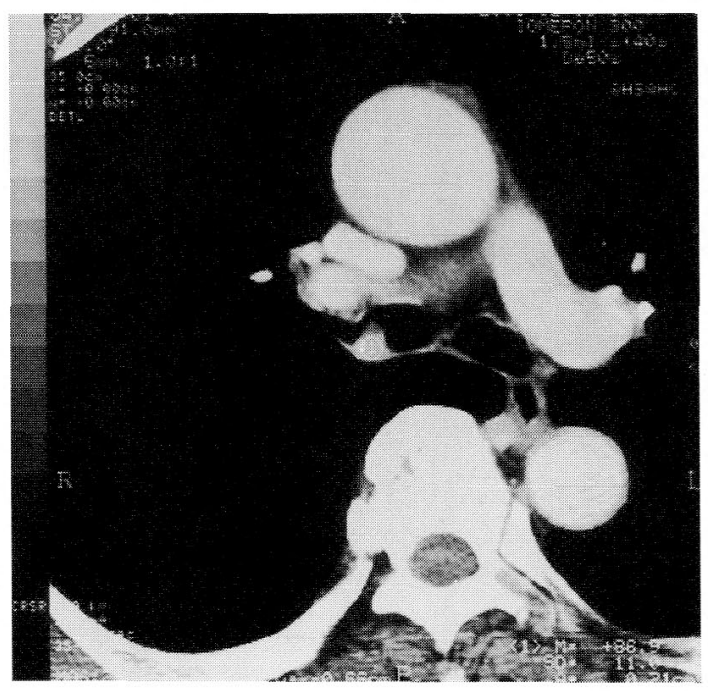

Figure 1. Chest CT scan showing a tumor arising in the right main bronchus at the level of the bifurcation of right upper lobe bronchus.

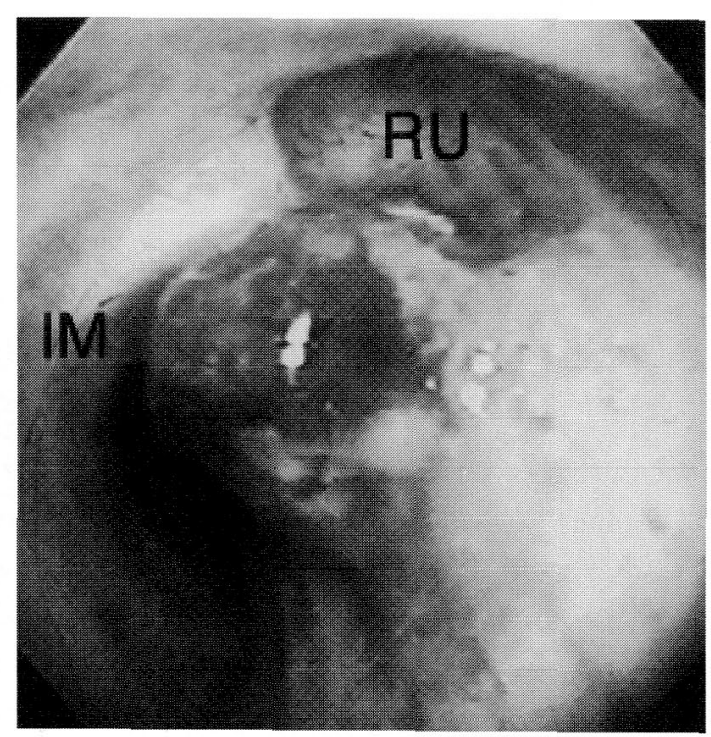

Figure 2. Bronchoscopy showing a tumor (approximately $1 \mathrm{~cm}$ in diameter) at the bifurcation of the right upper lobe bronchus (RU) and the truncus intermedius (IM).

ち, 腫瘍から約 $5 \mathrm{~mm}$ の距離を保って上葉気管支/中間幹 分岐部から膜様部にかけて切除した (Figure 3). 術中の 迅速診で，中枢側にあたる主気管支，および末梢側にあ たる上葉気管支と中間幹の切断線上に腫湯細胞の遺残が ないことを確認した。このことで膜様部を中心に直径約 $2 \mathrm{~cm}$ の欠損を生じたが, 通常の気管支吻合法を適用して 確実な再建を行うために，はじめに中間幹の軟骨部を軸 に直角に切除して，主気管支と中間幹を完全に離断させ 


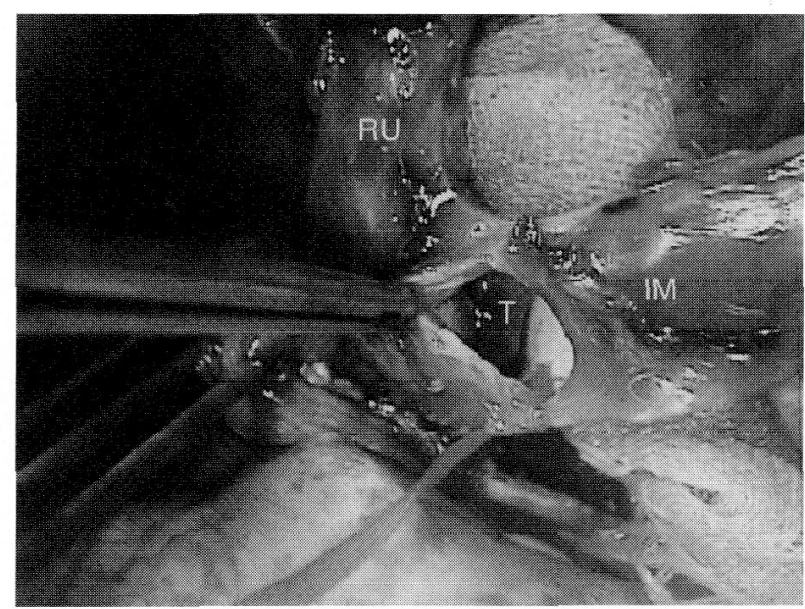

Figure 3. A tumor ( $\mathrm{T}$ ) was removed by resecting the bifurcation of the right upper lobe bronchus (RU) and the truncus intermedius (IM)
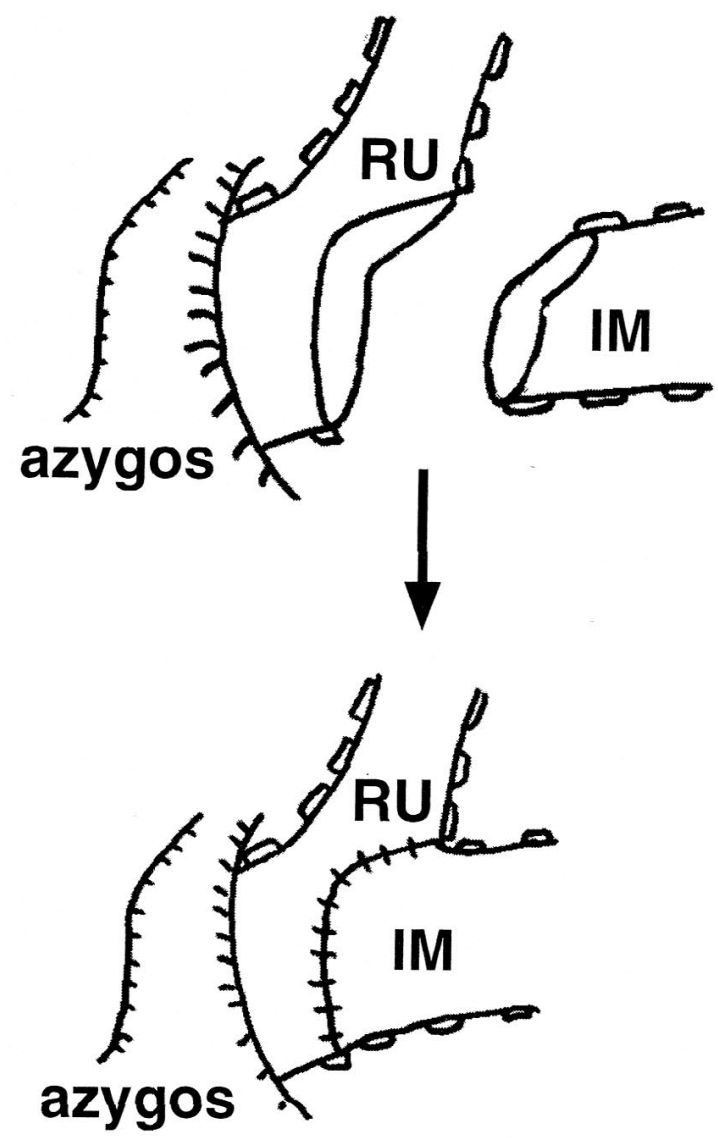

Figure 4. Schematic illustration of sleeve resection and anastomosis of the bronchus. RU indicates right upper lobe bronchus; and IM, truncus intermedius.

た。ただし，この状態では主気管支と上葉気管支は軟骨 部では連続していても，膜様部の欠損のために，吻合部 の中枢側は平面ではなく凹型である(Figure 4). そこで,

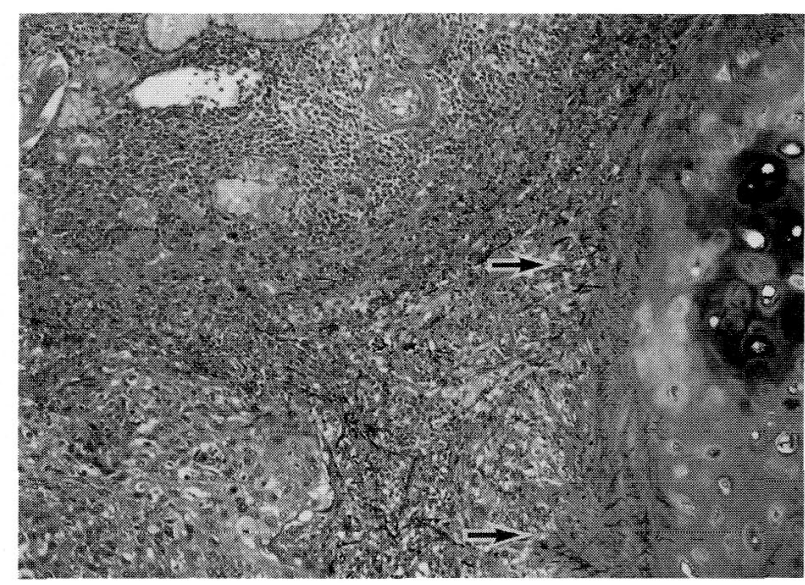

Figure 5. Microscopic findings of the resected tumor showing carcinoma infiltration and disruption of elastic fibers surrounding bronchial cartilage. Arrows indicates disrupted elastic fibers. Elastica-Masson staining. Original magnification, $\times$ 100.

これに対応するように中間幹側を中葉気管支入口部まで $1 \mathrm{~cm}$ の距離を残して凸にトリミングして吻合面を合致 させた (Figure 4). 吻合は 3-0 PDS 系を用いて，単結節で テレスコープ状に行った (Figure 4). $30 \mathrm{~cm}$ 水柱圧でシー リングテストを行い吻合部からの気漏がないことを確認 した。最後に第 5 肋間筋を吻合部全周に縫着して, 胸腔 ドレーンを留置して閉胸した。

病理組織所見：摘出した腫瘍は中分化型扁半上皮癌と 診断された。顕微鏡的には腫瘍は軟骨の近傍まで浸潤し ており，また軟骨周囲の弾性線維の断裂も認められた (Figure 5)。一力，腫瘍細胞の気管支壁外一の浸潤はな かった．摘出したリンパ節のすべてにおいて癌の転移は 認められなかった。

術後経過：術後第 2 病日に胸腔ドレーンを抜去した。 経過は良好で術後第 20 病日に退院した. 肺癌手術から 3 か月で再入院し, 胃全摘術とリンパ節郭清術を施行した が, 順調に経過し術後 24 日目に退院した. 肺癌手術から 8 か月での気管支鏡検査では, 吻合部は上幹, 中間幹とも 開存良好で腫瘍の雨発は認められなかった（Figure 6). 手術後の肺機能検查成績は良好に維持されていた (Table 1). 手術後 1 年の時点で局所再発や遠隔転移は認めず, 従来と変わらずに農業に従事している.

\section{考 察}

この症例では, 腫瘍は有上葉気管支/中間幹分岐部の比 較的狭い領域に限局しており，気管支壁外への進展もリ ンパ節転移もない早期癌と判断された。しかし, 気管支 壁内への浸潤が疑われるために, レーザー照射や photodynamic therapy（PDT）などの内視鏡的治療では根治 
は期待できない. 于術療法を考慮する場合, そのアプロー チとしてはスリーブ上葉切除という選択は一般的であろ うと思われる。あるいはスリーブ中下葉切除も技術的に は差異はないが，肺組織の袈失が前者に比較して大きい のが欠点である。しかし，そのいずれの場合でも，重要 なことは気管支切断端に腫瘍細胞が遺残しないことで あって，腫瘍の末梢にあたる在上葉気管支や中間幹より も末梢の肺組織を切除することは必ずしも必要ではな い.さらに, 中枢型の早期扁平上皮癌は同時性にも異時 性にも多発しやすい傾向があり, 2 将来, 気管支や肺の治 療が必要になった場合に備えて治療手段の選択に余地を 残す, という観点からも肺組織の温存は有意義である. そこで, 我々は, 術中に気管支切断端の迅速診断を行っ て腫瘍細胞の遺残がないことが確認できれば，右上葉気 管支/中間幹分岐部のみを切除する方針で手術を進める ことにした。

はじめに, 腫瘍の占拠部位である右上葉気管支/中間幹 分岐部から膜様部にかけて切除したが，このことで膜様 部を中心に直径約 $2 \mathrm{~cm}$ の欠損を生じることになった。

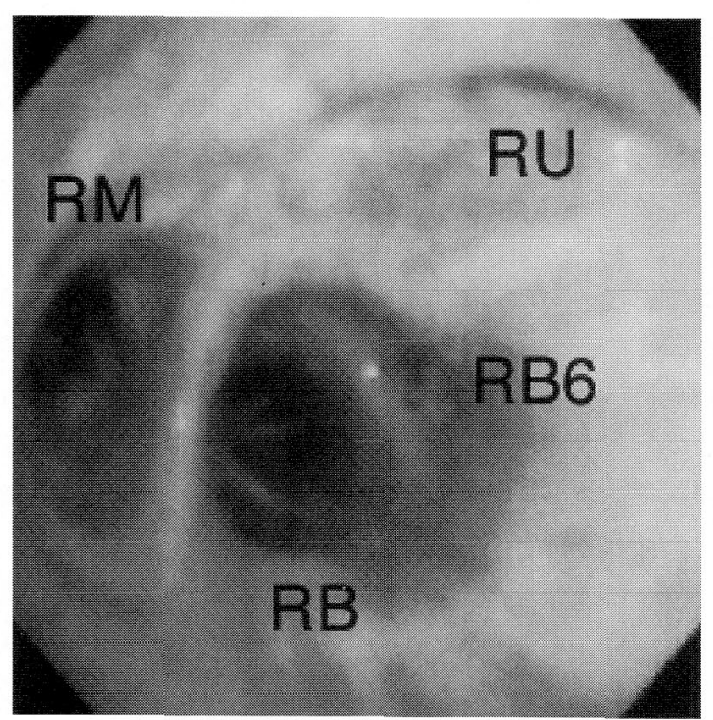

Figure 6. Bronchoscopy at 8 months after operation showing excellent results of bronchoplasty. RU indicates right upper lobe bronchus; and IM, truncus intermedius.
このような欠損部の修復には直接縫合して閉鎖する方法 も試みられている.1 あるいは, 肋間筋や心膜を用いた被 覆方法も適用し得るであろう. しかし, 我々は通常の気 管支吻合法を適用して確実な再建を行うことにした。こ のためには，はじめに軟骨部を軸に直角に切断して，主 気管支と中間幹を完全に離断させた。膜様部の欠損のた めに，主気管支と上葉気管支の連続性を維持したままで は吻合面は中枢側に凹の不定型であったが，これに対応 するように中間幹側の吻合面をトリミングして，我々が 通常に行っているテレスコープ状の吻合で再建すること ができた。吻合部の離断や狭窄などの合併症はなく，術 後 8 か月までに極めて良好な吻合部治癒が得られた。

肺癌手術後も全ての肺葉が温存されたことから，肺機 能検査成績にも著しい低下はなかった。手術後 1 か月の 時点で FVC などに軽度の減少を認めたが, これは開胸操 作そのものによる影響と考えられる。後側方切開では肺 実質を切除しなくとも，術後急性期に FVCが術前の約 $70 \%$ に減少するが，長期的には術前のレベルに回復す る. ${ }^{3}$ 実際, この症例でも FVC の減少は術後 3 か月でほ ぼ解消された。術後の肺機能が良好に維持できたことは, この症例の場合には次の胃癌手術に際しても呼吸器合併 症のリスクを下げる観点から非常に有利であったと考え ている.

このような肺実質の切除を伴わない気管支形成は，気 管支カルチノイドや顆粒細胞腫など比較的悪性度が低い 疾患に対してはしばしば適用されてきた方法である.4,5 しかし肺癌に対しては，これまでにいくつかの症例報告 がなされているが, 1,6-8 必ずしも広く認知された手術ア プローチとは言い難い。切除範囲を安易に縮小すること

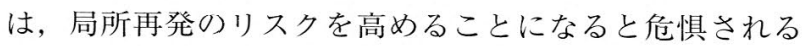
ためと思われる. しかし, 気管支切断面の組織学的検索 を行って, 腫瘍細胞の遺残がないことが確認できれば, 腫瘍の占拠部位よりも末梢の気管支や肺組織に病巣がな い以上，たとえ肺実質を含めた切除を行っても，そのこ とは肺癌治療の根治度を高めることにはつながらない. この症例のような中心型早期肺癌の中には, 肺切除を行 わなくとも，肺全摘除，あるいはスリーブ肺葉切除と同 じ根治度が期待できる症例が存在すると考えられる。腫 瘍の占拠部位などから慎重に選別された症例では，それ

Table 1. Results of lung function tests

\begin{tabular}{lccc}
\hline & Preoperative & 1 month & 3 months \\
\hline $\mathrm{FEV}(\mathrm{L})$ & 3.68 & 3.02 & 3.53 \\
$\mathrm{FEV}_{1}(\mathrm{~L})$ & 2.36 & 2.06 & 2.34 \\
$\mathrm{FEV}_{1} \%(\%)$ & 64.1 & 68.2 & 66.3 \\
Peak flow $(\mathrm{L} / \mathrm{min})$ & 6.08 & 5.96 & 6.13 \\
$\mathrm{~V}_{50}(\mathrm{~L} / \mathrm{min})$ & 1.51 & 1.71 & 1.72 \\
$\mathrm{DL}$ & 22.54 & 17.08 & 18.89 \\
\hline
\end{tabular}


らの特異性に合わせて, 手術根治度を下げることなく少 しでも肺機能を温存すべく, 肺切除を伴わない気管支形 成の適用が考慮されるべきであろう。

\section{REFERENCES}

1. Tsubota N, Yoshimura M, Murotani A, et al. Atypical bronchoplasty to lung cancer and benign bronchial disease. Tohoku J Exp Med. 1994;172:209-220.

2. Nakamura H, Kawasaki N, Hagiwara M, et al. Early hilar lung cancer-risk for multiple lung cancers and clinical outcome. Lung Cancer. 2001;33:51-57.

3. 野田雅史, 小野貞文, 鈴木聡, 他. 聴診三角切開と後側方 切開との比較から見た胸腔鏡下手術の肺機能に関する検 討. 胸部外科. 1997;50:368-372.
4. 寺島雅範, 篠永真弓, 瀧沢恒世, 他. 肺切除のない気管支 形成術で摘出できた右中幹気管支内カルチノイドの 1 例. 日胸外会誌. 1993;41:315-318.

5. 西村嘉裕, 加藤良一, 堀之内宏久, 他. 肺を温存して切除 できた右上葉原発の気管支カルチノイドの 1 例. 日胸外 会誌. 1978;35:1056-1059.

6. Frist WH, Mathisen DJ, Hilgenberg AD, et al. Bronchial sleeve resection with and without pulmonary resection. $J$ Thorac Cardiovasc Surg. 1987;93:350-357.

7. 水渡哲史, 吉津 晃, 後藤太一郎, 他. 右下葉の気管支管 状切除・再建を行った肺癌の 1 例. 気管支学. 2001;23:600 -603 .

8. 榊原直樹, 渡辺洋宇, 木元春生, 他. 二連銃様吻合再建を 施行した左上・下葉分岐部の肺門型早期肺癌の 1 治験 例. 日胸外会誌. 1987;35:1934-1938. 